\title{
Therapy of a schizoaffective disorder as a risk factor of perinatal complications and fetal developmental disorders
}

\section{Dominika Janeczko ${ }^{1}$ ADEF https://orcid.org/0000-0003-1085-3560, Magdalena Hołowczuk ${ }^{1}$} ADEF https://orcid.org/0000-0002-8501-5329, Anna Orzeł ${ }^{1}$ ADEF https://orcid.org/0000-0002-5908-6967, Barbara Klatka ${ }^{1}$ ADEF https://orcid.org/0000-0001-9693-7348, Małgorzata Neścior-Piech ${ }^{1}$ ADEF https://orcid.org/0000-0003-2037-4571, Michał Dzikowski² ADEF https://orcid.org/0000-0002-4252-7308

${ }^{1}$ Students Scientific Association at I Department of Psychiatry, Psychotherapy and Early Intervention, Medical University of Lublin

${ }^{2}$ I Department of Psychiatry, Psychotherapy and Early Intervention, Medical University of Lublin

\begin{abstract}
Introduction: Schizoaffective disorder is described as a combination of symptoms of schizophrenia and mood disorder components. It is estimated that in 2009 in Poland over 30 thousands women were treated in outpatient care because of schizotypical disorders, also in 2009, over 5,5 thousands Polish women, were hospitalised because of the same reason.

Material and method: We searched through whole medical documentation of the patient, which were available at the Department of Psychiatry and Gynaecology. We mainly focused on the last hospitalization of the woman. We found research connected to our subject on Science Direct website.

Discussion: A 34-year-old woman was admitted to Department of Psychiatry, patient was 14 weeks pregnant. Family described her behaviour as verbally and physically aggressive and dysphoric which forced her parents to take woman to the hospital. It was her third hospitalization. Pharmacotherapy was insufficient to improve the mental state of the woman. Doctors decided to carry out a series of electroconvulsive treatments (10 procedures). When woman was 36 weeks pregnant, there was a leak of green amniotic fluid and it was necessary to perform a caesarean section. A newborn required mechanical ventilation, had decreased muscle tone and facial dysmorphic features, also defect of the atrial septum was found.

Conclusions: Pregnant women with psychiatric disorders should be all considered high risk. It means that they need multidisciplinary care - psychiatrist, gynaecologist, neonatologist or other specialists, in order to stay in a good condition mentally and physically during pregnancy.
\end{abstract}

Keywords: schizoaffective disorder, congenital malformations, nicotinism, gestational diabetes

\section{Streszczenie}

Wstęp: Zaburzenie schizoafektywne jest opisywane jako połączenie objawów schizofrenii i zaburzeń nastroju. Szacuje się, że w Polsce w 2009 roku, ponad 30 tysięcy kobiet było leczonych ambulatoryjnie z powodu tego zaburzenia, a także w tym samym roku, ponad 5,5 tysiąca Polek było hospitalizowanych z powodu tej choroby.

Materiał i metody: Przeanalizowano dokumentację medyczną pacjentki obecną w archiwum oddziału psychiatrycznego i oddziału ginekologicznego. W szczególności skupiono się na ostatniej hospitalizacji pacjentki w szpitalu. Wszelkie informacje na temat choroby i leczenia odwołano do aktualnej literatury dostępnej w bazie danych Science Direct.

Dyskusja: 34-letnia kobieta została przyjęta na oddział psychiatryczny, pacjentka była w 14 tygodniu ciąży. Rodzina pacjentki opisywała jej zachowanie jako agresywne - zarówno w słowach jak i w czynach, a także dysforyczne, co skłoniło ich do przywiezienia kobiety do szpitala. Była to trzecia hospitalizacja psychiatryczna. Farmakoterapia nie była wystarczająca, by uzyskać poprawę stanu psychicznego. Zdecydowano przeprowadzić serię zabiegów elektrowstrząsowych. W 36 tygodniu ciąży doszło do odpłynięcia zielonych wód płodowych i zdecydowano o przeprowadzeniu cięcia cesarskiego. Noworodek wymagał mechanicznej wentylacji, miał obniżone napięcie mięśniowe, cechy dysmorfii twarzy oraz ubytek przegrody międzyprzedsionkowej. 
Wnioski: Kobiety ciężarne z zaburzeniami psychicznymi powinny być otoczone szczególną opieką psychiatry, ginekologa, neonatologa oraz innych specjalistów. Dzięki temu mamy pewność, że pacjentka pozostaje w dobrym stanie psychicznym i fizycznym w trakcie ciąży.

Słowa kluczowe: zaburzenie schizoafektywne, wady wrodzone, nikotynizm, cukrzyca ciężarnych

\section{Introduction:}

Schizoaffective disorder is a mental illness, which is described as a combination of symptoms of schizophrenia and mood disorder components. In 1933, an American psychiatrist - Jacob Kasanin proposed a name of this health condition as "schizoaffective disorder", and identified this as schizophrenia with acute affective disorders, including a few weeks or months remissions [1]. A patient can experience typical schizophrenia manifestations such as hearing voices, that do not exist, unclear thinking, hallucinations and many other. Moreover, at the same time, a person can feel depressed or is in a maniac mood or both of them - mixed type [2].

It is estimated that in 2009 in Poland over 30 thousands women were treated in outpatient care because of schizotypical disorders, also in 2009 , over 5,5 thousands Polish women were hospitalised because of the same reason [3]. The exact cause of this disorder is unknown. It is suspected, that genetics plays major role in development of this disease, as it occurs in families [1].

\section{Material and method:}

We searched through whole medical documentation of the patient, which were available at the Department of Psychiatry and Gynaecology. We mainly focused on the last hospitalization of the woman. We also found research connected to our subject on Science Direct website.

\section{Case report:}

A 34-year-old woman was admitted to Department of Psychiatry, patient was 14 weeks pregnant. A few weeks before hospitalization, her mental health was getting worse. Family described her behaviour as verbally and physically aggressive and dysphoric which forced her parents to take woman to the hospital. It was her third hospitalization. She was diagnosed with schizoaffective disorder maniac type when she was 16 years old, first episode ended up with stay at the Department of Psychiatry. Exacerbation of this disease ran in the form of rich psychotic experiences, thinking disorders, aggression and dysphoria.

In the initial period of the hospitalization, woman was aggressive towards other patients and medical staff, illogical in contact. Examples of her behaviour was hitting her head at the door, jumping from the window sill, destroying hospital equipment, or jerking hair and beating other patients. Because of the actions that threaten the life and health of the patient and other people in the hospital, she was staying in solitary confinement and placed in medical restraints multiple times. Woman has also been caught smoking cigarettes with other patients many times.

Pharmacotherapy for over five weeks including haloperidol, zuclopenthixol, olanzapine, valproate and levomepromazine was insufficient to improve the mental state of the woman. Doctors decided to carry out a series of electroconvulsive treatments (10 procedures), which improved a patient's condition to a small extent. She was less aggressive and could sleep whole night without waking up.

During hospitalization, she was regularly consulted by internist and gynaecologist. She had three USG examinations, but it did not show any congenital diseases. There was no information in medical records about perinatal infections or folic acid supplementation. Patient was diagnosed with gestational diabetes and undergone insulinotherapy. Her glycemic levels were systematically controlled, but because of non-compliance of the patient with a diabetic diet, therapy was not effective.

After many gynaecological consultations, doctors decided that it is necessary to carry out caesarean section, because patient's mental state was not good enough for cooperation during natural birth. When woman was 36 weeks pregnant, there was a leak of green amniotic fluid and it was necessary to perform a caesarean section. The premature baby at birth had 5-6-8-8 points on the Apgar scale, required mechanical ventilation, had decreased muscle tone and facial dysmorphic features. In the newborn the defect of the atrial septum was found. There was no more information about the baby. Patient's husband and parents took care of a newborn. After the delivery, the woman returned to the Department of Psychiatry for further therapy. Her mental condition was improving after giving birth. After one month she was discharged from the hospital.

\section{Discussion:}

The FDA classification is used to assess the risk of birth defects and anomalies for developing fetus during pharmacotherapy of the pregnant woman. Unfortunately, all of the antipsychotics are in a groups C and D of this classification, which means, they may have teratogenic 
effects on fetus [4].

Haloperidol is in a group D, and it also penetrates into breastmilk, this drug should be administered in the lowest possible dose. Zuclopenthixol is placed in a group C, but does not penetrate into breastmilk. Mothers can feed their child while using this pharmaceutical, but it is recommended to observe condition of a baby. Newborns of mothers who used this drug at the end of a pregnancy may have symptoms of poisoning, for example lethargy, hyperactivity or muscle tremors. Cases of feeding problems, extra-pyramidal, withdrawal symptoms or respiratory disorders have been reported between neonates. Olanzapine is atypical antipsychotic drug, which is located in a group C of FDA classification. It is forbidden to breastfeed while applying this drug. Valproate is marked in a group D. Many studies reported high risk of serious developmental disorders or congenital malformations in children exposed to valproate during their fetal life. This pharmaceutical may be found in small amounts in a breastmilk, but there were no adverse reactions observed among children. Levomepromazine is in a group $\mathrm{C}$, and it is also not recommended during breastfeeding [5]. Mentioned antipsychotics were used because of a bad mental health of the patient. Besides, they were not sufficient to improve woman's condition. These medicines could contribute to a bad state of a newborn, perinatal complications and his congenital defects.

As an alternative treatment, doctors proposed electroconvulsive therapy. Most of the available researches, indicate it as a safe for pregnant women and their baby [6]. Some of the side effects may be confusion, memory loss, increase of the heart rate or headache. But this treatment is still safer than pharmacotherapy for pregnant women [7].

It is estimated that 6-9\% pregnancies of mothers with gestational diabetes can lead to congenital malformations. It can also cause hypotrophy or pre-term delivery. The most common are defects of circulatory system and central nervous system [8]. This health condition could contribute to heart defects of a newborn, especially because diabetic diet was not followed by the patient.

Nicotinism during pregnancy can lead to sudden infant death syndrome (SIDS), which is death of a baby between the fourth week and the first year of life without any clear reason [9]. We have no further information about vitality of a child of our patient. There is no connection between congenital defects of a newborn and mother smoking cigarettes, but there is higher risk of premature rupture of membranes (PROM) [10], or Intrauterine Growth Restriction (IUGR) [11].

\section{Outcome:}

Pharmacotherapy could contribute to preterm delivery, perinatal complications and congenital malformations of the newborn.

Nicotinism and mechanical injuries are the things that cannot be predicted and doctors should try to prevent these, using medical restraints or isolating patient.

Complications with a newborn and his face dysmorphia were probably due to pharmacotherapy (especially valproate) conducted during pregnancy, but it is impossible to certainly say what was the reason. Also gestational diabetes could contribute to congenital malformations of a child. There is not enough evidence in researches that electroconvulsive therapy is dangerous for newborn. There were multiple risk factors that could contribute to a bad state of a child.

It is necessary to educate the patient about reducing the risk of congenital defects in newborn. Particular care should be given to people at high risk, for example, those receiving anti-psychotic drugs.

\section{Conclusions:}

Pregnant women with psychiatric disorders should be all considered high risk. It means that they need multidisciplinary care - psychiatrist, gynaecologist, neonatologist or other specialists in order to stay in a good condition mentally and physically during pregnancy.

\section{Conflict of interest}

The authors have declared no conflict of interest.

\section{References:}

1. Jarema M, Rabe-Jabłońska J: Psychiatria 2016; wyd. 2: 125-137.

2. Mayoclinic.org. Mayo Clinic Staff.: Schizoaffective Disorder 2017; [cytowana 6 czerwca 2019]. Dostępna z: https://www. mayoclinic.org/diseases-conditions/schizoaffective-disorder/ symptoms-causes/syc-20354504

3. Główny Urząd Statystyczny: Zdrowie kobiet w Polsce w latach 2004-2009.

4. www.fda.gov. Food and Drug Administration: Classification of drugs during pregnancy; [cytowana 6 czerwca 2019]

5. Indeks leków Medycyny Praktycznej: 2019.

6. Bulbul F, Copoglu US, Alpak G, Unal A, Demir B, Tastan MF, Savas HA: Electroconvulsive therapy in pregnant patients. Gen Hosp Psychiatry. 2013;35:636-9.

7. Mayoclinic.org. Mayo Clinic Staff.: Electroconvulsive therapy (ECT) 2018; [cytowana 6 czerwca 2019]

8. Łagoda K, Kobus G, Bachórzewska-Gajewska H: Wpływ cukrzycy ciążowej na rozwój płodu i noworodka. Endokrynol. Otył. Zab. Przem. Mat. 2008; 4:168-173.

9. Polańska K, Hanke W. Palenie papierosów przez kobiety ciężarne a przebieg i wynik ciąży - przegląd badań epidemiologicznych. Przegl Epidemiol. 2004; 58: 683-691.

10. Milnerowicz H, Zalewski J, Geneja R, Milnerowicz-Nabzdyk E, Woyton J, Levels of $\mathrm{Cd}, \mathrm{Pb}$ in blood and $\mathrm{Zn}, \mathrm{Cu}, \mathrm{Cd}, \mathrm{Pb}$ in amniotic fluid of tobaccosmoking women during pregnancy complicated oligohydramnios orpremature rupture of membranes, Ginekol. Pol. 2000;311-316. 
11. Milnerowicz-Nabzdyk E, Bizon A, Effect of cigarette smoking on vascularflows in pregnanciescomplicated by intrauterine growth restriction, Reprod.Toxicol. 2014;27-35.

Otrzymano:12.08.2019

\section{Corresponding author}

Zrecenzowano:29.08.2019

Dominika Janeczko

I Klinika Psychiatrii, Psychoterapii

i Wczesnej Interwencji,

ul. Głuska 1 (SPSK Nr 1) Lublin 20-439

dominika.janeczko@gmail.com 